\title{
ESTIMATING DEMAND FOR PUBLIC RURAL ROADS IN TEXAS
}

\author{
Laurence M. Crane, Nat Pinnoi, and Stephen W. Fuller*
}

\begin{abstract}
Following Bergstrom and Goodman, private demand functions for publicly provided rural roads in Texas are estimated at the county level. Results show the effect of income and tax rate (price) to have the expected effect and the demand for rural roads to have changed over time. In particular, demand has become more inelastic, and the influence of income on demand has moderated.
\end{abstract}

\section{INTRODUCTION}

Many rural economies have undergone a major restructuring resulting from an accelerated exodus from farming, increased unemployment, and the subsequent declines in tax base and population. The economic downtum has been further compounded in oil-producing states where there has been a decline in the value of oil production. There is concern about the ability of rural governments to provide roads and bridges as well as other essential public services and infrastructure (U.S. Department of Agriculture 1991; Johnson, Deaton, and Segarra 1988; Chicoine and Walzer 1986).

In recognition of the transportation problems in rural America, former U.S. Secretary of Transportation Skinner recently designated "Rural America Transportation Systems and Services" as one of the critical problem areas in U.S. transportation. And, as such, he recently authorized the development of a national transportation policy to establish guidelines for meeting the nation's transportation needs over the next decade and into the twenty-first century (Federal Register 1989). In view of this impetus, it seems important to leam more about the economic forces that have shaped the demand for rural transportation infrastructure so that rational policies might be developed and forwarded.

Earlier studies have investigated means of reducing the supply of rural road infrastructure (e.g., road abandonment). This study in contrast examines factors that affect the demand for publicly provided rural roads. The objective of this study is to examine appropriate methodology to determine the demand for rural road infrastructure and subsequently to estimate the demand for rural roads in

\footnotetext{
*Assistant Professor, Department of Agricultural Economics, North Dakota State University and formerly Research Associate, Texas Transportation Institute, Texas A\&M University; Assistant Research Scientist, Texas Transportation Institute, Texas A\&M University; and Professor, Department of Agricultural Economics, Texas A\&M University, respectively.
} 
Texas. The results will provide policymakers with valuable information on economic forces (income, price) influencing the demand for rural roads, thus enabling them to develop better policies to address the problem of supplying privately demanded but publicly supplied rural roads.

\section{PREVIOUS RESEARCH}

Rural transportation arteries are an important link between farmers, markets, and rural employment centers. Agriculture depends on the timely marketing of commodities and products and on purchased inputs, both of which move over the rural road system. In spite of the importance of the rural road system, it has deteriorated, and there is general concem (Chicoine, Walzer, and Deller 1989; U.S. Department of Transportation 1985). Recent studies have analyzed disinvestment in rural low-volume roads and bridges (Nyamaah and Hitzhusen 1985; Hartwig 1979; Baumel, Schomhorst, and Smith 1989). Studies show cost of improving and upgrading major parts of the system exceed resources available to rural local governments (Baumel and Schomhorst 1983; Chicoine 1987). Expenditures for public highways support the third largest function of state and local govemments; expenditures for education and welfare are first and second, respectively (Anderson, Murray, and Farley 1984).

The deteriorated physical and financial condition of the public rural road system has been exacerbated by the increasing number of rail line abandonments by private railroads (Casavant and Lenzi 1989). Furthermore, structural shifts in rural America have dramatically changed the types of traffic on the rural road system. Increased farm size has resulted in a dramatic reduction in farm numbers and population. This has been accompanied by an increase in the size and weight of vehicles and equipment on the rural road system. These heavy and often overweight vehicles breakup road surfaces, while the frequent lack of paved surfaces creates dust, rideability, and safety problems.

Narrow lanes and other design characteristics on many of these roads are inadequate for modem trucks thus creating safety hazards. Similarly, deficient rural bridges pose serious safety and traffic constraints. Some states that have not been able to generate sufficient revenues have downgraded the size of their rural system through road abandonment and private provision (Hamlett and Baumel 1990; Baumel, Schomhorst, and Smith 1989; Hartwig 1979).

In Texas, there are approximately 134,000 miles of rural roadway and 17,000 rural bridges, the largest rural road network in the United States (Texas Almanac 1988); U.S. Department of Transportation 1985). Maintaining these roads, many of which are low-volume, is a major expense of local highway budgets (U.S. 
Department of Commerce 1982). State govermment in Texas supplies about 17 percent of the funds for rural roads through motor fuel taxes (U.S. Department of Transportation 1985).

\section{METHODOLOGY}

Traditional demand theory is oriented to the behavior of the individual consumer. The market demand relation is simply a gross aggregation of the demands of all individual consumers. In this framework, the individual's utility function is assumed to be strictly increasing in all arguments, smooth, quasi-concave, and twice-continuously differentiable. This utility function is maximized subject to a linear budget constraint. The ratio of the partial derivatives from the first-order conditions are the marginal rates of substitution between the goods in an individual's utility function. The solution to this problem yields the Marshallian demand function that relates quantities demanded to given levels of prices and income.

Goods and services that are publicly supplied generally share two characteristics that distinguish them from private goods. First, consumption by any one person need not diminish the quantity consumed by anyone else, and second, it is impossible to confine the benefits of the good to selected persons (Buchanan 1968; Browning and Browning 1983). Because of these characteristics, aggregate consumption patterns are consistent with utility maximization only when restrictions are placed on the shapes of individual preferences. However, the results from public sector studies based on the utility maximization paradigm have verified that most of the classical conditions hold.

Rather than viewing expenditures as responses to collectively exercised demands, Deacon (1978) incorporates the possibility of substitution among public services in response to changes in relative costs by directly modeling and estimating the substitution effects in collective consumption. Deacon carries out the analysis using the classical consumer choice model, which assumes a separable utility function is maximized subject to a linear budget constraint. Deacon found the negativity and homogeneity properties of utility maximization held, thus suggesting classical demand theory is appropriate for analyzing public sector expenditures. That is, public budgets are allocated among public goods and services in the same theoretical manner that individuals allocate income to private sector goods.

Since a public good simultaneously benefits all members of the community, each of these individual's marginal valuations must be accounted for when the resource allocation decision is made. Samuelson $(1954,1955)$ has shown the 
Pareto optimal condition for a public good requires the following first order condition be satisfied,

$$
\sum_{i=1}^{n} M R S_{x y}^{i}=M R T_{x y},
$$

where, $n$ is the number of community members, $y$ is a private sector good, and $x$ is the public good. This condition, referred to as the Samuelsonian condition, is obtained by maximizing the utility of any individual while the utility levels of the individuals comprising the community are held constant (Comes and Sandler 1986; Starrett 1988; Boadway and Wildasin 1984).

As the relative costs of publicly provided goods and services change, demand theory suggests that there will be a substitution effect. To test this notion, Ehrenberg (1973) estimated wage elasticities of demand for different categories of state and local government employees and found that an increase in the relative price of a public service led to a substitution against that service. Conceptually, alternative modes of transportation service may substitute for each other, however, for practical purposes there is no close substitute for the public rural road system. Currently, the only altemative to the rural road system is the railroad. And, as Casavant and Lenzi (1989) have documented, users of these systems are forced to substitute the rural road system for abandoned rural rail lines.

Variations in per capita expenditures on public services, such as highways, health, and education, are often explained by population densities, urban-rural distinctions, average income levels, and age distributions. Ohls and Wales (1972) noted that theory is not clear on whether these demographic variables enter on the demand or supply side of the market.

Borcherding and Deacon (1972) used the theory of collective decisionmaking to posit a model of public spending and to test the significance of the variables assumed by collective decision theory to be important determinants of state and local government expenditures. The effects of income, price, city size, and other social variables on the demand for municipal services were estimated by Bergstrom and Goodman (1973).

In principle, it is possible to observe directly the choices that individuals of particular demographic groups make, under alternative price and income situations, for privately produced commodities. For obvious reasons, this is generally not the case with publicly supplied commodities. Bergstrom and Goodman made inferences about the effect of price, income, and other relevant variables on individual demands for municipal services by making strong assumptions about the political process of municipalities. 
Rubinfeld (1987) pointed out that aggregation of preferences, measurement of output, and determination of price are conceptual problems in estimating public demands. Assumptions ${ }^{1}$ of the Bergstrom and Goodman model overcome the major conceptual problem of preference aggregation outlined by Rubinfeld.

\section{SPECIFIED MODEL AND ESTIMATION TECHNIQUE}

In this paper, a variation of the Bergstrom and Goodman (1973) model is estimated using the sample of 254 counties in the state of Texas for 1972 and 1986. The usefulness of the publicly provided goods (rural roads in our case) to an individual is a function of the total number of users and the quantity of such goods. Mathematically this can be stated as:

$$
Q^{*}=n^{-v} Q
$$

where,

$Q^{*} \quad$ is the usefulness of rural roads to a user,

$\mathrm{n}$ is the total number of road users,

Q is the total quantity of rural roads,

$v \quad$ is a crowding parameter (i.e., if $\mathrm{Q}$ is a pure public good, then $v=0$, and if $v=1$, then every user shares the same amount of the facility).

All individuals are assumed to maximize their utility functions, consisting of both private and public goods, subject to their budget constraints. Mathematically, this maximization problem is formulated as:

$$
\underset{X_{i}, Q^{*}}{\operatorname{Max}} U_{i}\left(X_{i}, Q^{*}\right),
$$

Subject to, $\quad X_{i}+\tau_{i} q Q \leq Y_{i}$,

or equivalently by substituting in (1), the budget constraint becomes

$$
X_{i}+\tau_{i} q n^{\nu} Q^{*} \leq Y_{i},
$$

where $q$ is a unit cost of the rural roads (assuming that the unit cost of private goods is unity), $\tau_{\mathrm{i}}$ is a tax share, $X_{\mathrm{i}}$ is private goods, and $Y_{\mathrm{i}}$ is the budget of individual $i$. If we assume further that income and price elasticities, $\eta_{\mathrm{y}}$ and $\eta_{\mathrm{p}}$, for $Q^{*}$ are constant, then the derived demand for $Q^{*}$ can be written as a Cobb-Douglas function: 


$$
A\left(\tau_{i} q n^{v}\right)^{\eta_{p}} Y_{i}^{\eta_{y}}
$$

Therefore, the demand function (after taking a natural logarithm) for rural roads is $a+\alpha \ln n+\eta_{P} \ln \tau+\eta_{Y} \ln Y$, where $\alpha=v\left(1+\eta_{P}\right)$.

Under the assumption that $\tau_{\mathrm{i}}$ and $q_{\mathrm{i}}$ are constant, the county's expenditure on rural roads and streets can be considered as the quantity of rural roads demanded. Finally, the estimated demand for rural roads is described below as:

$$
\ln R E X P=\mathrm{a}+\alpha \ln n+\eta_{\mathrm{P}} \ln \tau+\eta_{\mathrm{Y}} \ln Y+\sum_{j=1}^{G} \theta_{j} Z_{j},
$$

where,

$Z_{j}$ 's are variables representing specific characteristics for Texas counties, a, $\theta_{\mathrm{j}}$ are parameters to be estimated, and

$R E X P$ is the total annual expenditure on roads and streets by a county.

Let $X$ be a matrix of all the independent variables with its corresponding vector of parameters $\beta$, and rexp a column vector of $\ln (R E X P)$, then in matrix form:

$$
\operatorname{rexp}=X \beta+u, \text { where } u-\left(0, \sigma^{2}\right) .
$$

Demands are estimated by ordinary least squares (OLS) for the 1972 and 1986 samples as well as the pooled sample.

\section{Empirical Model}

The empirical model (6) can be rewritten with the selected auxiliary variables for the rural road system in Texas, including the county characteristics as:

$$
\operatorname{lnREXP}=a+\alpha \ln n+\eta_{\mathrm{P}} \ln \tau+\eta_{\mathrm{Y}} \ln Y+\sum_{j=1}^{5} \theta_{j} Z_{j},
$$

where $n$ is a measure of the number of road users. In the empirical model, the average annual daily traffic (AADT) on the rural farm to market (FM) system in the county is a proxy for $\mathrm{n}$, while $Y$ is nonfarm per capita income in the county, ${ }^{2}$ and $\tau$ is per capita tax value upon which the tax rate is levied in each county. The five auxiliary variables are total county road mileage, county area, population density, and dummy variables for agricultural and metropolitan counties. In- 
clusion of the dummy variables control for unmeasured county-specific conditions. It is conjectured that the demand for publicly provided roads would be greater for metropolitan counties than agricultural counties. It is thought that economic and social activities in the metropolitan counties would require more frequent use of the roads than in the nonmetropolitan counties.

Similar to any consumer demand analysis, we expect price (represented by $\tau$ ) to have a negative effect on quantity demanded and the demand for roadways to increase as income and county population increase. Likewise, we would expect population density, county area, and road mileage to have a positive impact on road demand.

\section{Data}

The data set consists of annual observations for the 254 counties of Texas for the years 1972 and 1986 . The 1972 sample was selected because it was the last year before the oil crisis. The 1986 sample was selected because it was the most current year for which complete data were available on all of the variables at the county level. Following Bergstrom and Goodman (1973), the county expenditures on road maintenance and construction (REXP) were used to represent the demand for rural roads. These highway maintenance and construction expenditures are reported by the Texas Department of Transportation (TxDOT) in their biennial reports. As expected, capital spending on new construction and maintenance expenditures had increased substantially by 1986 .

Data on personal income and population were from a U.S. Department of Commerce source (Regional Economic Information System), and the per capita $\operatorname{tax}(\tau)$ was calculated using county data from the Texas State Property Tax Board. Personal income had increased by 1986 as had population for the state as a whole. However, population had declined in several of the more rural 254 counties. With few exceptions, taxes as measured for this study had increased as well.

Data on miles of rural roads and the average annual daily traffic are available from the TxDOT, and data on county size were taken from the Texas Almanac. Obviously, county size had not changed from 1972 to 1986, but the miles of roads had increased. The AADT increased in most counties, but it had decreased in those counties that experienced a drop in population and in those counties where the population was more concentrated relative to 1972.

The different classifications of counties (e.g., metropolitan, nonmetropolitan, agricultural, manufacturing, mining, etc.) used in this study are those used by the U.S. Department of Agriculture, Economic Research Service (Ross and Green 1985). Also, to exclude the effects of inflation, nominal dollar values were 
deflated using the GNP implicit price deflators $(1982=100)$ in the Economic Report of The President.

\section{Misspecification Tests}

Because cross-sectional data were used, a series of misspecification tests were conducted to test and correct for heteroscedasticity ${ }^{3}$ and structural changes ${ }^{4}$ over time. Specifically, White's general test for heteroscedasticity and a Wald test were performed to test and correct for the stabilization of the estimated coefficients over time.

\section{RESULTS}

White's (1980) general test for heteroscedasticity shows the empirical model suffers from unequal error variances (Table 1). In the absence of a priori information on the known structure of the heteroscedasticity, a Feasible Generalized Least Squares is precluded. A Chow test for structural change is invalid when heteroscedasticity occurs. Altematively, we rely on a Wald statistic that is unaffected by the inequality of the variances, given a large sample. The null hypothesis of equality between the two sets of regressions ( 1972 and 1986 samples) is rejected at the 1 percent level as a Type I error (Table 1). Therefore, the results of the two cross-section subsamples should be more precise than the pooled regression. As such, attention is focused on the separate models rather than on the pooled model.

Approximately 60 percent of the variation in demand for county roads in Texas was explained by the selected set of regressors (Table 1). The explanatory power of the equations estimated by Bergstrom and Goodman (1973) ranged from 35 percent to 96 percent. Based on White's general test for heteroscedasticityconsistent estimates of the covariances, most coefficients are statistically significant at the 5 percent level or higher except for the coefficient on income (significant at 15 percent) based on the 1986 sample. Furthermore, the point estimates of all parameters possess the expected sign, except for the coefficient on the per capita tax variable in the pooled sample, but it is statistically insignificant.

As expected, as nonfarm per capita income increases by 1 percent, the demand or expenditure for rural roads is estimated to increase by 0.48 percent and 0.21 percent, based upon the 1972 and 1986 data, respectively. The estimated income elasticities suggest rural road demand was less sensitive to the changes in income in 1986 than in 1972. Real per capita income was increasing in 93 percent of the counties in 1972 but was increasing in only 51 percent of the counties in 1986. Further, as the "price" of rural roads increases by 1 percent, the expenditure 
TABLE 1

Estimated Model Parameters

\begin{tabular}{|c|c|c|c|}
\hline $\begin{array}{l}\text { Independent } \\
\text { Variables } \\
\end{array}$ & $\begin{array}{c}\text { First Subsample } \\
1972 \\
\end{array}$ & $\begin{array}{c}\text { Second Subsample } \\
1986 \\
\end{array}$ & $\begin{array}{c}\text { Pooled } \\
1972 \text { and } 1986 \\
\end{array}$ \\
\hline Constant & $\begin{array}{l}9.05^{*} \\
(2.00)\end{array}$ & $\begin{array}{r}7.62^{*} \\
(2.30)\end{array}$ & $\begin{array}{l}8.33^{*} \\
(1.54)\end{array}$ \\
\hline $\begin{array}{l}\text { In(nonfarm per } \\
\text { capita income) }\end{array}$ & $\begin{array}{l}0.48^{*} \\
(0.17)\end{array}$ & $\begin{array}{r}0.21^{* * * *} \\
(0.15)\end{array}$ & $\begin{array}{l}0.35^{*} \\
(0.13)\end{array}$ \\
\hline In(tax per capita) & $\begin{array}{l}-0.25^{*} \\
(0.10)\end{array}$ & $\begin{array}{l}-0.19^{*} \\
(0.07)\end{array}$ & $\begin{array}{c}0.02 \\
(0.03)\end{array}$ \\
\hline $\ln (\mathrm{AADT})$ & $\begin{array}{l}0.15^{* *} \\
(0.07)\end{array}$ & $\begin{array}{l}0.30^{*} \\
(0.09)\end{array}$ & $\begin{array}{r}0.14^{*} \\
(0.057)\end{array}$ \\
\hline $\begin{array}{l}\text { Crowding } \\
\text { parameter }\end{array}$ & $\begin{array}{r}0.2^{*} \\
(0.09592)\end{array}$ & $\begin{array}{r}0.37^{*} \\
(0.1621)\end{array}$ & $\begin{array}{c}0.14^{*} \\
(0.05468)\end{array}$ \\
\hline $\begin{array}{l}\text { Rural roads } \\
\text { mileage }\end{array}$ & $\begin{array}{c}0.003^{*} \\
(0.001)\end{array}$ & $\begin{array}{l}0.003^{*} \\
(0.001)\end{array}$ & $\begin{array}{c}0.004^{*} \\
(0.0007)\end{array}$ \\
\hline County area & $\begin{array}{r}0.00024^{*} \\
(0.0001)\end{array}$ & $\begin{array}{r}0.00017^{* *} \\
(0.00009)\end{array}$ & $\begin{array}{l}0.00016^{*} \\
(0.00006)\end{array}$ \\
\hline $\begin{array}{l}\text { Agricultural } \\
\text { county }\end{array}$ & $\begin{array}{c}-0.45^{*} \\
(0.13)\end{array}$ & $\begin{array}{l}-0.30^{*} \\
(0.12)\end{array}$ & $\begin{array}{l}-0.43^{*} \\
(0.09)\end{array}$ \\
\hline $\begin{array}{l}\text { Metropolitan } \\
\text { county }\end{array}$ & $\begin{array}{l}0.50^{*} \\
(0.13)\end{array}$ & $\begin{array}{c}0.54^{*} \\
(0.14)\end{array}$ & $\begin{array}{l}0.70^{*} \\
(0.11)\end{array}$ \\
\hline Population density & $\begin{array}{r}0.0003^{*} \\
(0.00006) \\
\end{array}$ & $\begin{array}{r}0.0002^{*} \\
(0.00005) \\
\end{array}$ & $\begin{array}{c}0.0002^{*} \\
(0.00005)\end{array}$ \\
\hline $\mathbf{R}^{2}$ adjusted & 0.59 & 0.62 & 0.57 \\
\hline White's test & $1,466,092$ & $\begin{array}{r}599,546 \\
3000\end{array}$ & 239,001 \\
\hline $\begin{array}{l}\text { Wald test } \\
\text { Chow test }\end{array}$ & & $\begin{array}{l}39.09 \\
11.13\end{array}$ & \\
\hline
\end{tabular}

Standard errors computed from White's heteroscedasticity-consistent covariance matrix are given in parentheses.

*Statistically significant at 1 percent.

**Statistically significant at 5 percent.

***Statistically significant at 15 percent.

or demand for rural roads decreases by 0.25 percent based on the 1972 sample and by 0.19 percent based on the 1986 data. This suggests taxpayers were slightly more responsive to price changes in 1972 than 1986 . This may be due to an increase in the level of traffic congestion experienced by road users in some rural counties as well as a deterioration in the quality of the rural system.

The above finding is consistent with Peterson (1990), who reports approximately 25 percent of infrastructure proposals (the majority of which are for 
highways and streets) were approved by households in a 1990 study. During the 1970s, approval rates for proposed public expenditures were as low as 30 percent. However, during the late 1980 s, taxpayers approved 80 percent of all state and local infrastructure bond proposals. Furthermore, the average margin of approval exceeded 66 percent, significantly higher than any other type of expenditure referendum. Evidently, taxpayers were willing to buy more infrastructure than was actually furnished by the state and local governments.

Consumption of public goods by one person diminishes the quantity consumed by another. Consequently, a crowding parameter was estimated to measure this effect. A zero crowding parameter would indicate a pure public good, whereas a parameter value of one would indicate a pure private good. A crowding parameter of less than one, but greater than zero, suggests the public investment is not a pure public commodity. In this study, the crowding parameter is estimated to be 0.37 in 1986 and 0.2 in 1972, indicating that the road system in Texas experienced greater utilization in 1986. Thus, an additional road user would decrease the availability of the roads to others but would not completely prevent other motorists from using the roads. Bergstrom and Goodman (1973) found the estimates of crowding parameters for municipal, police, and parks and recreation expenditures were generally equal to one or greater. Their results imply that ". . as the size of municipalities increase, the advantages of sharing the cost of public services among more persons are countervailed by the cost of sharing the services among more persons." In summary, income elasticity is greater in 1972 than 1986. In contrast, the price elasticity and the crowding parameter are increasing over time.

A series of dummy variables were used to determine if the social and economic characteristics of the county affected the demand for roads. Counties were classified as either metropolitan or as nonmetropolitan. The nonmetropolitan counties were then sorted according to a subclassification, depending upon the dominant characteristic of that county. The possible subclassifications for the nonmetropolitan counties were agricultural, manufacturing, mining, federal lands, government, poverty, or retirement. The demand for rural roads in metropolitan counties and in nonmetropolitan agricultural counties were found to be the only statistically significant dummy variables. The negative parameter estimates for the agricultural county dummy variable and the positive values for the metropolitan county variable indicate that, on average, the demand for rural roads in agricultural counties is less than the demand in metropolitan counties. 


\section{SUMMARY AND CONCLUSIONS}

The demand for rural roads in Texas, using county data from 1972 and 1986 , is estimated following the procedure developed by Bergstrom and Goodman. The estimated demand relationships are consistent with consumer theory and generally comparable with earlier results. The sign and magnitude of the coefficients are reasonable, and in no case was an estimated coefficient both significant and of perverse sign. The effect of income on rural road demand was found to vary from 0.48 in 1972 to 0.21 in 1986, while the influence of tax rate (price) on demand varied from -0.25 in 1972 to -0.19 in 1986. This outcome suggests some change in the effect of income and tax rate (price) on the demand for rural roads over time. In particular, demand has become more inelastic, and the influence of income on demand has moderated. A less favorable economic climate in 1986 relative to 1972 may offer some explanation. Further, the fact that rural roads in Texas are increasingly more crowded may partially explain the observed changes.

Estimates of the demand for rural roads provide important information for analyses of current public policy issues. Rural roads in Texas are financed by local, state, and federal funds, and over time declining real resources from nonlocal sources have increased the price of rural roads to local taxpayers. As such, the effect of changing revenue sources actually depends on the demand elasticity. Further, the demand and slope parameter provides insight regarding tax revenues that might be obtained by local governments through adjustments in tax rates. In addition, the efficiency of local government in maintaining rural road infrastructure subsequently influences local tax rates; consequently, the implications of changing costs (efficiency) may be evaluated with knowledge of demand and the associated elasticity.

The crowding parameters offer insight into the individual's per capita share of the public road that is provided. Values between 0 and 1 indicate goods that show partly public and partly private characteristics. As the parameter value approaches 1, the road exhibits more characteristics of a pure public good and less characteristics of a private good. The crowding parameters we estimated are not as large as those reported in some other studies; however, they are increasing over time as the system becomes more congested. A general observation is that the road network of 1986 was largely completed when compared to the network existing in 1972; therefore, the demand for rural roads tends to exhibit more public good characteristics over our sample period. One would expect on a county-bycounty basis to find crowding parameters for the more urban counties to be large relative to rural counties.

Finally, there have been few efforts to measure the demand for rural road infrastructure in the United States. This study demonstrates the feasibility of es- 
timating these demands and relates how this type of information might serve as useful input to rural road policy. Future research that addresses specific policy issues would be a useful application of this approach.

\section{ENDNOTES}

1. Specifically, Bergstrom and Goodman assumed that (1) the income distributions for different jurisdictions are simple proportional shifts of each other, (2) all individuals have identical constant elasticities of demand for the public good being considered, and (3) income and price elasticities are related in a manner that the distribution of desired demands is a monotonic function of income. These restrictive assumptions, in conjunction with the median voter assumptions, show one possible set of sufficient conditions where public expenditures on goods in the jurisdiction can be treated as the amount demanded by an individual with the median income in the jurisdiction. Obviously, the shortcomings of this approach are the restrictive nature of the median voter model and the additional restrictions on the income and price elasticities imposed by Bergstrom and Goodman. The shortcomings of the median voter model are well documented and thoroughly discussed in the extant literature. The work by Rubinfeld (1987) is an excellent recent source for a discussion of the Bergstrom and Goodman assumptions and corresponding limitations.

2. Per capita farm income, as well as total per capita income, were also used as a measure of average county income. However, when these variables were included the results were not satisfactory (e.g., explanation declined and the expected signs on several of the key variables were not obtained).

3. Given the cross-sectional nature of our data, heteroscedasticity would be expected. White's general test for heteroscedasticity, without any prior knowledge of its structure, is therefore a recommended test. Although OLS estimates will be consistent under heteroscedasticity, the estimated covariance matrix of the estimated parameters will depart from its true value even in the case of a large sample. Consequently, any statistical inference about the estimated coefficients based on its covariance (e.g., t-test for statistical significance of the parameters estimated by OLS) will be inaccurate. However, White (1980) showed that a heteroscedasticity-consistent estimate of the covariance can be obtained from OLS residual

$$
\operatorname{VAR}[\hat{\beta}]=n\left(X^{\prime} X\right)^{-1} S\left(X^{\prime} X\right)^{-1},
$$

where 


$$
S=\frac{1}{n} \sum_{i=1}^{n} e_{i}^{2} x_{i} x_{i}^{\prime}, \text { and } e_{\mathrm{i}} \text { is OLS residual; } i=1, \ldots, n
$$

4. A Wald test is performed instead of a simple Chow test in order to test the stabilization (over time) of the estimated coefficients (i.e., to test whether two sets of OLS estimators are the same). It is well known that the Chow test will be invalid in the case where the two models have unequal variances (i.e., when heteroscedasticity is present). The result of the Chow test will reject the null hypothesis of no structural change "too" often. Since our sample is reasonably large, the Wald asymptotical tests were calculated with an assumption that the disturbance terms from the two separate regressions are independently and normally distributed. This condition is plausible because the two sample periods are 15 years apart; consequently, it is reasonable to believe that the errors are unlikely to be correlated. The result of the Wald test will be valid whether the two error variances are equal or not.

$$
W=\left(\hat{\beta}_{1}-\hat{\beta}_{2}\right) /\left(V_{1}+V_{2}\right)^{-1}\left(\hat{\beta}_{1}-\hat{\beta}_{2}\right) \underset{\tilde{H}_{0}}{\alpha} \chi_{\mathrm{K}}^{2},
$$

where

$$
\begin{aligned}
& \hat{\beta}_{i}, i=1 \text { and } 2 \text {, is the vector of OLS estimators from two separate } \\
& \text { regressions, } \\
& \mathrm{V}_{i, i}, 1 \text { and } 2 \text {, is the estimated covariance matrix of the OLS estimates, } \\
& \mathrm{K}, \text { is the number of parameters estimated (i.e., dimension of } \beta \text { ). }
\end{aligned}
$$

The Wald statistic, $W$, is asymptotically distributed as a chi-square distribution with $K$ degree of freedom.

\section{REFERENCES}

Anderson, James E., Richard W. Murray, and Edward L. Farley. Texas Politics. New York: Harper and Row, 1984.

Baumel, C. Phillip, and Eldo Schomhorst. "Local Rural Roads and Bridges: Current and Future Problems and Altematives." Transportation Research Record 898 (1983): 374-378.

Baumel, C. Phillip, Eldo Schomhorst, and Wesley D. Smith. "Alternatives for Solving the Local Rural Road and Bridge Problem." In Profitability and Mobility in Rural America, edited by W. R. Gillis. University Park: The Pennylvania State University Press, 1989. 
Bergstrom, Theodore C., and Robert P. Goodman. "Private Demand for Public Goods." The American Economic Review 63(1973): 280-296.

Boadway, Robin W., and David E. Wildasin. Public Sector Economics. 2d ed. Boston: Little, Brown, 1984.

Borcherding, Thomas E., and Robert T. Deacon. "The Demand for the Services of

Non-Federal Governments." The American Economic Review 62(1972): 891901.

Browning, Edgar K., and Jacquelene M. Browning. Public Finance and the Price

System. 2d ed. New York: Macmillan Publishing Co., Inc., 1983.

Buchanan, James M. The Demand and Supply of Public Goods. Chicago: Rand McNally and Company, 1968.

Casavant, Kenneth L., and J. C. Lenzi. "Predicting Financial Impacts on Rural

Roads of Potential Rail Line Abandonments." Transportation Research Record 1229 (1989):62-70.

Chicoine, David L. "Issues and Implications of the Financial Crisis in Agriculture:

The State/Local Govemment Finance Dimension." Agricultural Finance Review 47 (Special Issue 1987): 62-71.

Chicoine, David L., and Norman Walzer, eds. Financing Local Infrastructure in Nonmetropolitan Areas. New York: Praeger Press, 1986.

Chicoine, David L., Norman Walzer, and Steven C. Deller. "Financing Rural Roads and Bridges: Issues and Trends." In Profitability and Mobility in Rural America, edited by W. R. Gillis. University Park: The Pennsylvania State University Press, 1989.

Cornes, Richard, and Todd Sandler. The Theory of Externalities, Public Goods, and Club Goods. New York: Cambridge University Press, 1986.

Deacon, Robert T. "A Demand Model for the Local Public Sector." The Review of Economics and Statistics 60(1978): 184-192.

District and County Statistics. Finance Division, Texas State Department of Highways and Public Transportation, Austin, Texas, October 1988.

Economic Report of the President. Washington, D.C.: U.S. Government Printing Office, February 1988.

Ehrenberg, Ronald G. "The Demand for State and Local Govemment Employees." The American Economic Review 63(1973): 366-379.

Federal Register. Vol 54, no. 126, Monday, July 3, 1989.

Hamlett, Cathy A., and C. Phillip Baumel. "Rural Road Abandonment: Policy Criteria and Empirical Analysis." American Journal of Agricultural Economics 72(1990): 114-120.

Hartwig, William. "Rural Road-Closure Program to Preserve Agricultural Land." Transportation Research Record 716 (1979). 
Johnson, Thomas G., Brady J. Deaton, and Eduardo Segarra, eds. Local Infrastructure Investment in Rural America. Boulder, Colo.: Westview Press, 1988.

Nyamaah, Kofi, and Fred Hitzhusen. "A Circuity Model for Rehabilitation/Closure of Rural Bridges." North Central Journal of Agricultural Economics 7(1985): 41-50.

Ohls, James C., and Terence J. Wales. "Supply and Demand for State and Local Services." The Review of Economics and Statistics 54(1972): 424-438.

Peterson, George E. "Is Public Infrastructure Undersupplied?" In Is There a Shortfall in Public Capital Investment?, edited by Alicia H. Munnell. Proceedings of a Conference Held at Harwick Port, Massachusetts, sponsored by that Federal Reserve Bank of Boston, June 1990.

Regional Economic Information System. Bureau of Economic Analysis, U.S. Department of Commerce, Washington, D.C., 1989.

Ross, Peggy J., and Bernal L. Green. "Procedures for Developing a Policy Oriented Classification of Nonmetropolitan Counties." Staff Report no. AGES850308. U.S. Department of Agriculture, Economic Research Service, Washington, D.C., August 1985.

Rubinfeld, Daniel L. "The Economics of the Local Public Sectors." In Handbook of Public Economics, Vol. II, edited by A. J. Auerbach and M. Feldstein. Elsevier Science Publishers B.V (North Holland), 1987.

Samuelson, Paul A. "The Pure Theory of Public Expenditure." The Review of Economics and Statistics 36(1954): 387-389.

. " Diagrammatic Exposition of a Theory of Public Expenditures." The Review of Economics and Statistics 37(1955): 350-356.

Starrett, David A. Foundations of Public Economics. New York: Cambridge University Press, 1988.

1988-1989 Texas Almanac and State Industrial Guide. Dallas: A.H. Bello Corp., Communications Center, 1988.

U.S. Department of Agriculture. Transportation in Rural America: A Policy Backgrounder. Transportation and Marketing Division, Agricultural Marketing Service, USDA, Washington, D.C., April, 1991.

U.S. Department of Commerce. 1982 Census of Government, Governmental Organization. Washington, D.C., 1982

U.S. Department of Transportation. Highway Statistics-1985. Washington, D.C.: Federal Highway Administration, 1985.

White, H. "A Heteroscedasticity-Consistent Covariance Matrix Estimator and a Direct Test for Heteroscedasticity." Econometrica 48(1980): 817-838. 